\title{
Technical Change, Technical Efficiency, and Their Impact on Input Demand in the Agricultural and Manufacturing Sectors of Pakistan
}

\author{
KARAMAT ALI and ABDUL HAMID
}

\begin{abstract}
Technical change has been considered as one of the most important determinants of economic growth. In developed economies, a proportionately higher percentage of GDP growth is attributable to technological progress and technical efficiency. However, technical change in developing countries is in its early stages and increased use of factor inputs is still the dominant source of economic growth. An attempt has been made in this paper to analyse technological progress and technical efficiency and their contribution to economic growth along with other factors of production by using more efficient methods in the manufacturing and agriculture sectors of Pakistan. There are a few studies on technological growth and technical efficiency change in Pakistan but they suffer from certain limitations. Most of them use the terms of technical change and productivity synonymously. Further, all of them use Hicks's formula of neutral technical change and assume that technical change is happening at a constant rate. We have attempted to measure technical change, technical efficiency, and productivity in the form of the Hicks neutral technical change as well as in the form of variable and continuous and discrete technical change. Besides, this paper also analyses the impact of technical change on input demand (i.e., its impact on labour and capital demand) and examines the issue of technical change being either labour-saving or capital-saving. We found that technical change was taking place at a continuous and variable rate. The major contributor to the growth of output and value-added in both sectors was capital, contributing over 50 percent. Labour share was about 20 percent in the agriculture sector and about 10 percent in the manufacturing sector. Technical change share was very significant in manufacturing but not so in agriculture. The manufacturing sector in Pakistan has grown at an annual rate of about 6 percent during 1970s and at 8.7 percent during 1980s, and its share in GDP has increased from 16.5 percent to about 19 percent, but it has failed to generate new employment opportunities for the labour force. The employment growth rate is only about 2 percent.
\end{abstract}

\section{INTRODUCTION}

Economic growth is one of the most important purposes of development policy in almost every country. Growth depends on the available factors of

Karamat Ali and Abdul Hamid are Professor and Lecturer, respectively, in the Department of Economics, Bahauddin Zakariya University, Multan.

Authors' Note: We are thankful to Mr Habib Ahmad and to an anonymous referees of this journal for helpful comments on an earlier version of this paper. 
production like an accumulation of capital and labour, better allocation of resources, institutional development, technological progress, and technical efficiency. Technical change has long been considered to be one of the most important determinants of economic growth. Even so, it must be recognised, as has been pointed out by Salter (1966); Nadiri (1970); Kennedy and Thrilwall (1972); Nelson (1981), and others. [see Wizarat (1989) and Yanrui (1995)], that because of the complementarity among various sources of growth, it is not possible to quantify the exact contribution of each source. However, economists like Solow (1957); Kendrick (1956); Denison (1967); Griliches (1963); Robinson (1971); Cornwell et al. (1990); Fecher and Pestieau (1993), and others [see Kemal (1992); Kang and Kwon (1988) and Yanrui (1995)], provide incisive methods with which to study the growth experience of a country.

In developed economies, a proportionately higher percentage of GDP growth is attributable to technological progress and technical efficiency. However, technical change in developing countries is in its early stages and an increased use of factor inputs is the dominant source of economic growth. In the LDCs, typically, two-thirds of the factor input contribution to GDP growth is due to capital. ${ }^{1}$ Despite the significance of technological development in the growth process, Pakistan, like many other developing countries, has focused on the accumulation and development of physical resources and inputs and has made very little attempt to increase the productivity of the factors of production.

The technological progress and its contribution to economic growth in Pakistan has been analysed by Kemal (1981, 1992); Ahmed (1980); Cheema (1978); Wizarat $(1981,1989)$ and Burney (1986). However, these studies suffer from certain limitations.

This paper analyses technological progress and technical efficiency and its contribution to economic growth along with other factors of production in the manufacturing and agricultural sectors of Pakistan. The plan of the paper is as follows: literature on economic growth and technical change is reviewed in Section II. Section III discusses the methodology and data sources. The empirical findings are given in Section IV. And, finally, policy implications and conclusions are presented in Section V.

\section{REVIEW OF LITERATURE}

Abramovitz (1956) analysed the role of technical change in economic growth for the US labour market for the period 1900-1950 and found out that almost twothirds of the increase in labour productivity was not explained by the increase in availability of capital per worker. Solow (1957) and some other economists

${ }^{1}$ As has already been mentioned, due to complementarity of factors of growth it is not possible to quantify the exact contribution of each source. Here an approximation is made. 
[Ferguson (1965); Kendrick (1973); Schultz (1964) and Hulten (1973)] also reported similar results for subsequent periods. [See Hassan (1988).]

The residual which could not be explained by the factors of production was termed 'co-efficient of ignorance' by Abramovitz and is now called technological progress and technical efficiency. Solow (1960) tried to quantify this residual-a manifestation of increase in productivity —and argued that it was owing to technical change.

Technological progress and technical efficiency in developing countries was estimated by various authors. For example, Bhavani (1991) estimated technical change in the manufacturing sector of India and found a significant share of it in industrial growth. [See Yanrui (1995).] Jefferson and Rawski (1988); Yanrui (1995), and some others estimated technical efficiency for the agriculture and manufacturing sectors of China. Yanrui found out that technical share was 53 percent in the state industrial sector, 58 percent in the rural industrial sector, and 55 percent in the agricultural sector of the Chinese economy. However, for most developing countries, technical change contribution is very low as compared to the DCs. Robinson (1991) estimated technical efficiency contribution in 39 developing countries and found out that, on the average, the increase in productivity was about 15 percent. This is a much smaller percentage attributable to technical change than that in developed countries. [For detail, see Kemal (1992).]

Kemal (1981) estimated the rate of technical change for the manufacturing sector for the period 1959-60 to 1969-70. His estimates for technical change differ depending on the form of the production function. He found decreasing returns to scale for total manufacturing, with all the different specifications. Kemal (1992) further estimated technical change and productivity for the whole economy along with the agricultural and manufacturing sectors of Pakistan. However, these studies suffer from certain limitations. First, he used various functional forms to get estimates of technical efficiency in 1981 without determining which functional form is appropriate for which industry. In 1992, he used the ratio method to determine productivity and technological and technical change. He used the terms technical change and productivity synonymously without any justification. He was, therefore, unable to explain the reason for the discrepancy between the rates of growth of technical change and productivity.

Cheema (1978) studied technical change and productivity growth in the manufacturing sector of Pakistan. He found rapid growth trends in productivity. However, such results were to be expected as he used the Census of Manufacturing Industries (CMI) data without making any adjustment.

Ahmed (1980) estimated productivity growth in the manufacturing sector of Pakistan for the period 1958-70. He found gains in labour productivity, but these were low. [See Wizarat (1989).] 
Wizarat (1981) estimated technological change in Pakistan's agricultural sector. She also estimated technical change for the manufacturing sector of Pakistan in 1989. While her results are quite interesting, they suffer from various limitations such as her use of approximation for capital instead of the exact value of capital stock and her assumption that technology in the manufacturing sector was growing at a constant rate.

Burney (1986) estimated sources of growth for the entire economy and found out that technical change contribution in the value-added was more than half of the total during sixties; it fell during the seventies and again rose during the period from 1980 to 1985.

From a review of the literature it becomes clear that there are a few studies on technological growth and technical efficiency change in Pakistan, but they all suffer from certain limitations. Most of them use the terms 'technical change' and 'productivity' synonymously. ${ }^{2}$ Further, all of them use the Hicks neutral technical change and assume that technical change is happening at a constant rate. We have attempted to measure technical change, technical efficiency, ${ }^{3}$ and productivity in the form of Hicks neutral technical change as well as in the form of a variable and continuous and discrete growth of technical change. Besides, this paper also analyses the impact of technical change on the inputs demand, i.e., the impact on the labour and capital demand, and discusses whether technical change is labour-saving or capital-saving.

\section{METHODOLOGY}

Technical change is defined as a shift in the production function. In specifying the best form of production function with which to measure technical change, we have several options: Cobb-Douglas; Kmenta’s approximation to the CES production function; or Translog production function pioneered by Christensen et al. (1973). Here we will use the Cobb-Douglas and translog techniques to measure technical change in the agricultural and manufacturing sectors of Pakistan.

With regard to the specification of technical change, the following specifications are used:

$e^{\lambda{ }^{t}}=$ Hicks neutral technical change or constant growth of technical change. $e^{\lambda{ }^{t}}{ }_{1}{ }^{\lambda}{ }_{2}{ }^{2}=$ Variable and continuous growth of technical change.

$e^{\lambda t}{ }_{1}+{ }_{2}^{\lambda D}=$ Variable and discrete growth of technical change (where $D$ is a dummy variable). ${ }^{4}$

${ }^{2}$ Productivity is the sum of technical change and technical efficiency.

${ }^{3}$ Technical change or technological progress increases the productivity by shifting the production function while technical efficiency increases productivity along the existing production function. For further detail, see Fare, Grosskopf, Norris and Zhang (1994) and Hassan and Grabawski (1988).

${ }^{4}$ Dummy variable takes the value of zero for the years from 1971 to 1980, 1988, 1992 and the value of one for the remaining sample. 
The Cobb-Douglas production function with constant, variable, and discrete technical change is written as:

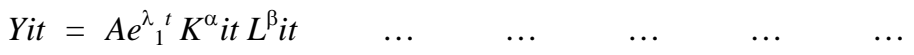

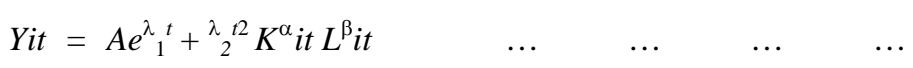

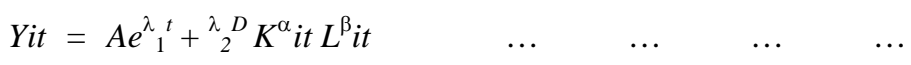

Where

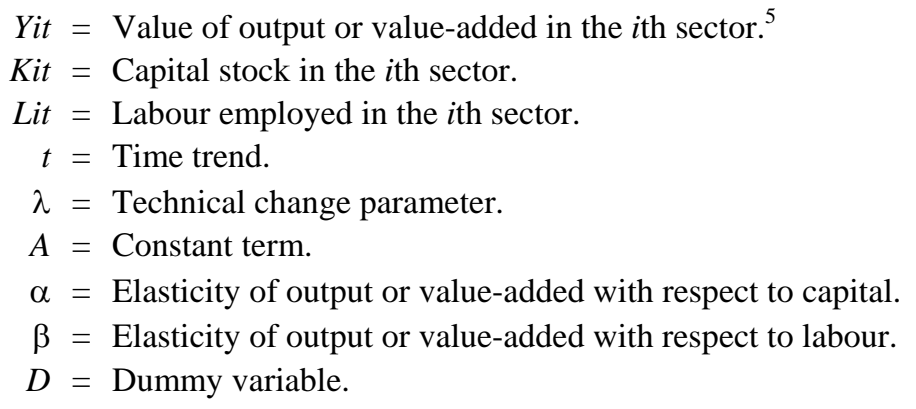

In the log form, the above three equations may be written as:

$$
\begin{array}{lll}
\ln Y i t=\ln A+\lambda_{1} t+\alpha \ln K i t+\beta \ln L i t+U i t & \ldots & \ldots \\
\ln Y i t=\ln A+\lambda_{1} t+\lambda_{2} t^{2}+\alpha \ln K i t+\beta \ln L i t+U i t & \ldots & \ldots \\
\ln Y i t=\ln A+\lambda_{1} t+D \lambda_{2}+\alpha \ln K i t+\beta \ln L i t+U i t & \ldots & \ldots
\end{array}
$$

If we include intermediate inputs, then Equation (1) can be written as:

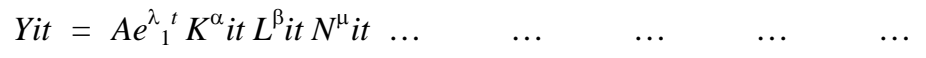

Where Nit $=$ Intermediate inputs in the ith sector.

If there is multicollinearity in Equations (1), (2), (3), these equations can be rearranged as follows. Rearranging Equation (2).

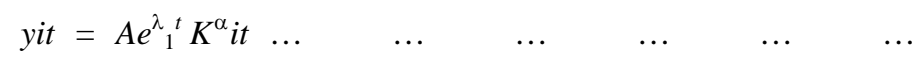

Where $y i t=$ Yit $/$ Lit, kit $=$ Kit $/$ Lit,$\alpha=1-\beta$.

Equation (2) in the estimatable form can be written as:

$$
\ln (Y i t / L i t)=\ln A+\lambda_{1} t+\lambda_{2} t^{2}+\alpha \ln (\text { Kit/Lit })+U i t \quad \ldots \quad \ldots
$$

${ }^{5}$ Here the sectors are agriculture and manufacturing. 
The translog production function for labour, capital, and technology can be written as:

$$
\begin{aligned}
& \ln Y t=\alpha_{0}+\lambda t+\alpha_{k} \ln K t+\alpha_{L} \ln L t+(1 / 2) \alpha_{k k}(\ln K t) \\
& +(1 / 2) \alpha_{L L}(\ln L t)^{2}+\alpha_{K L} \ln K t \ln L t \quad \ldots \quad \ldots
\end{aligned}
$$

The following homogeneity constraints are implied in the translog production function:

$$
\begin{aligned}
\alpha_{k}+\alpha_{L} & =1 \\
\alpha_{k k}+\alpha_{K L} & =0 \\
\alpha_{L L}+\alpha_{K L} & =0
\end{aligned}
$$

Subject to the homogeneity constraints in the translog production function, it will be estimated in conjunction with a cost share function with cross-equation restrictions imposed, a method suggested by Berndt and Christensen (1973). Since the cost share of capital and labour add to unity, only the labour cost share function is estimated. The labour cost share equation is derived as:

$$
C S_{L}=\delta \log Q / \delta \log L=\log \alpha_{L}+\alpha_{L L} \log L+\alpha_{K L} \log K \quad \ldots
$$

Where $C S_{L}$ is the labour share of total cost.

\section{Technical Efficiency}

Cornwell et al. (1990) introduced a time-varying efficiency approach. According to this measure,

$$
Y^{\bullet}=\lambda+\sum \gamma j X^{\bullet} i j(t)+T E^{\bullet} i(t) \quad \ldots \quad \ldots \quad \ldots \quad \ldots \quad \ldots
$$

Where the overdots indicate percentage changes. Equation (11) implies that output growth can be decomposed into three components: technical change $(\lambda)$, input growth $\left(\sum \gamma j X^{\bullet} i j(t)\right)$, and technical efficiency $\left(T E^{\bullet} i(t)\right)$. Technical efficiency measurement depends on two steps. In the first step, Equations (1), (2) and (3) are estimated and residuals are saved and then regressed against time trend as:

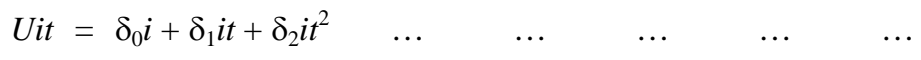

Thus the total factor productivity for Equation (2) can be written as:

$$
\operatorname{TFP}(t)=\left(\lambda_{1}+2 \lambda_{2} t\right)+\left(\delta_{1} i+2 \delta_{2} i t\right) \quad \ldots \quad \ldots \quad \ldots
$$

Where TFP $=$ Total factor productivity.

$\left(\lambda_{1}+2 \lambda_{2} t\right)=$ Continuous and variable technical change.

$\left(\delta_{1} i+2 \delta_{2} i t\right)=$ Time-varying technical efficiency. 


\section{The Impact on Input Demand}

To measure the impact of technical changes on input demand, we shall use the Hicksian definition of technical change bias:

$$
d \ln S i=(d \ln W i / d \ln T) d \ln T-(d \ln W j / d \ln T) d \ln T \quad \ldots
$$

Technical change is $\mathrm{Xi}$-saving or $\mathrm{Xi}$ - using according to whether the righthand side of Equation (14) is negative or positive. Where Wi \& Wj are prices of inputs.

\section{Data Description}

The model discussed above is used to measure the technical change, technical efficiency, and its impact on factor input demand for the period 1973-1995, using a time series data of value of output and value-added, capital stock, labour employed, and intermediate inputs in the agricultural and manufacturing sectors of Pakistan. Data on the value of output and value-added and cost of labour in the manufacturing sector are taken from Economic Surveys (1989-90, 1994-95). Data on the employed labour force are taken from Labour Force Surveys (1973-74 to 1991-92) and Economic Surveys (1989-90, 1994-95). Data on the capital stock and intermediate inputs in the agricultural and manufacturing sectors are taken from the report of the Sub-committee on Sources of Growth in Pakistan [Kemal and Ahmad (1992)].

The Cobb-Douglas production function is estimated using the OLS technique, while the Translog function is estimated by Zellner's efficient estimation procedure, also known as Seemingly Unrelated Regression (SURE) Technique. [See Zellner (1962, 1963).] The estimated results are reported in Section IV.

\section{EMPIRICAL FINDINGS}

The empirical results obtained from the Cobb-Douglas production function are given in Table 1. We have estimates both for value-added and output for the agricultural and manufacturing sectors of Pakistan for the period 1972-73 to 1994-95. Most of the results are statistically significant and according to expectation. The technical progress in almost all equations is estimated in the form of continuous and variable technical change. The results of this estimate are significant and according to expectation. We have empirically found that technical change is taking place at a continuous and variable rate equal to $\lambda_{1}+2 \lambda_{2} t$ both in agriculture and manufacturing. (See Table 2.) The co-efficients of other factor inputs are also significant. We have measured technical efficiency ${ }^{6}$ using Equation (12) and found out that technical efficiency has been taking place in the manufacturing sector of

\footnotetext{
${ }^{6}$ Uit was regressed against time trend and the results showed that the technical efficiency growth was constant equal to 0.0034 .
} 
Ali and Hamid

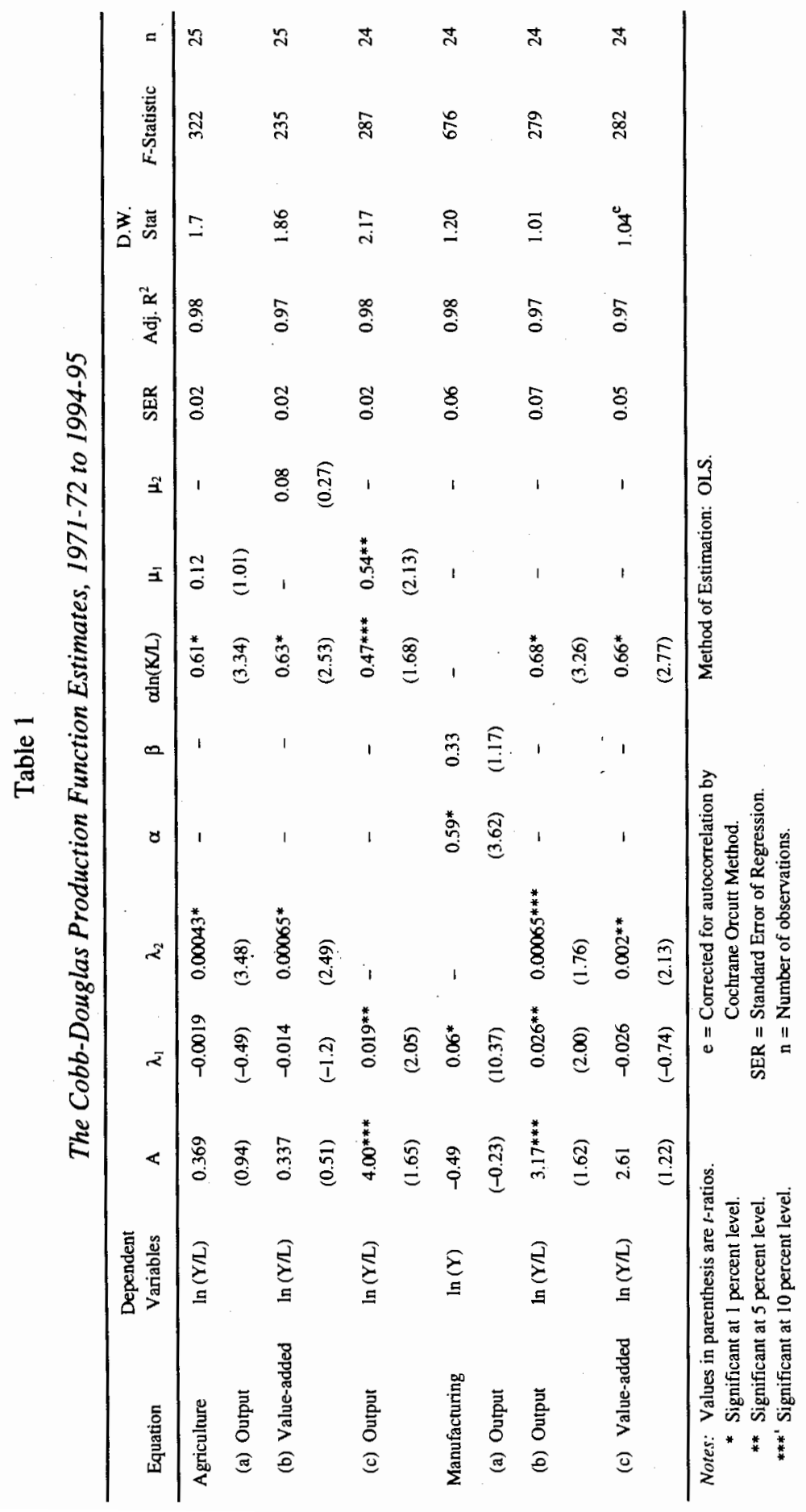


Table 2

Parameter Estimates of the Translog Restricted Production Function for the Manufacturing Sector, 1973-74 to 1994-95

\begin{tabular}{ccc}
\hline Co-efficient & $\begin{array}{c}\text { Output } \\
\text { Estimation }\end{array}$ & $\begin{array}{c}\text { Value-added } \\
\text { Estimation }\end{array}$ \\
\hline$\alpha_{0}$ & $3.41^{* *}$ & $3.01^{* * *}$ \\
& $(2.25)$ & $(1.54)$ \\
$\lambda$ & $0.047^{*}$ & $0.036^{*}$ \\
$\alpha_{\mathrm{k}}$ & $(7.32)$ & $(4.8)$ \\
$\alpha_{\mathrm{L}}$ & 0.71 & 0.67 \\
& $0.29^{*}$ & $0.33^{* *}$ \\
$\alpha_{\mathrm{KK}}$ & $(2.67)$ & $(2.33)$ \\
& -0.014 & -0.019 \\
$\alpha_{\mathrm{LL}}$ & $(-1.29)$ & $(-1.32)$ \\
$\alpha_{\mathrm{KL}}$ & -0.014 & -0.019 \\
$\mathrm{SER}$ & 0.014 & 0.019 \\
ADJ. R & 0.07 & 0.11 \\
$F-S t a t$. & 0.97 & 0.94 \\
$\mathrm{n}$ & 299 & 135 \\
\hline
\end{tabular}

Note: The method of estimation is Zellner's Seemingly Unrelated Regression Technique (SURE): $\alpha_{k}, \alpha_{\mathrm{LL}}$ and $\alpha_{\mathrm{KL}}$ are derived from constraints.

* Significant at 1 percent level.

** Significant at 5 percent level.

*** Significant at 10 percent level.

constant rate equal to 0.0034 . The contribution of growth of technical change and technical efficiency, and of factor inputs to growth of agricultural and manufacturing output and value-added, has been reported in Table 3.

The results show that the largest contribution was that of capital. Capital share in total growth of output and the value-added in the agricultural sector was 61 percent and 68 percent, respectively. Labour share in the value-added and output of agriculture was 18 percent and 17 percent, respectively. Technical change and technical efficiency contributed 21 percent and 14 percent to output and value-added, respectively, in the agricultural sector of the economy. However, in the manufacturing sector of the economy, the share of technical change and technical efficiency was very significant during the sample period. It contributed 36 percent to output growth and about 30 percent to value-added growth in the manufacturing sector. The share of capital in the manufacturing output and value-added was about 60 percent, and that of labour was about 10 percent. 


\section{Table 3}

The Contributions of Growth of Technical Change and Technical Efficiency, and of Factor Input to Growth of Agriculture and Manufacturing Output and Value-added

\begin{tabular}{|c|c|c|c|}
\hline Variable & Agriculture & Manufacturing ${ }^{7}$ & Manufacturing $^{8}$ \\
\hline Output Growth Rate & 3.92 & 7.73 & 7.73 \\
\hline Value-added Growth Rate & 3.62 & 6.79 & 6.79 \\
\hline Labour Growth Rate & 1.78 & 1.76 & 1.76 \\
\hline Capital Growth Rate & 3.92 & 6.1 & 6.1 \\
\hline Share of Labour in Value-added & 0.37 & 0.34 & 0.33 \\
\hline Share of Capital in Value-added & 0.63 & 0.66 & 0.67 \\
\hline Weighted Labour Growth Rate & 0.6586 & 0.5984 & 0.581 \\
\hline Weighted Capital Growth Rate & 2.4696 & 4.03 & 4.1 \\
\hline Share of Labour in Output & 0.39 & 0.32 & 0.29 \\
\hline Share of Capital in Output & 0.61 & 0.68 & 0.71 \\
\hline Weighted Labour Growth in Output & 0.6942 & 0.56 & 0.53 \\
\hline Weighted Capital Growth in Output & 2.39 & 4.2 & 4.33 \\
\hline \multicolumn{4}{|l|}{ Total Factor Input Growth Rate in } \\
\hline Value-added & 3.1282 & 4.63 & 4.7 \\
\hline \multicolumn{4}{|l|}{ Total Factor Input Growth Rate in } \\
\hline $\begin{array}{l}\text { Technical Change and Technical } \\
\text { Efficiency Growth Rate in } \\
\text { Value-added }\end{array}$ & 0.4918 & 2.16 & 2.09 \\
\hline $\begin{array}{l}\text { Technical Change and Technical } \\
\text { Efficiency Growth Rate in } \\
\text { Output }\end{array}$ & 0.8358 & 2.9 & 2.8 \\
\hline \multicolumn{4}{|c|}{$\begin{array}{c}\text { Sources of Growth as a Percentage of Output and } \\
\text { Value-added Growth }\end{array}$} \\
\hline Labour's Contribution (Output) & 17.7 & 8 & 8 \\
\hline Labour's Contribution (Value-added) & 18.2 & 9 & 9 \\
\hline Capital's Contribution (Output) & 61 & 55 & 56 \\
\hline Capital's Contribution (Value-added) & 67.8 & 60 & 61 \\
\hline $\begin{array}{l}\text { Total Factor Inputs Contribution } \\
\text { (Output) }\end{array}$ & 78.7 & 64 & 64 \\
\hline $\begin{array}{l}\text { Total Factor Inputs Contribution } \\
\text { (Value-added) }\end{array}$ & 86.0 & 69 & 70 \\
\hline $\begin{array}{l}\text { Technical Change and Technical } \\
\text { Efficiency Contribution }\end{array}$ & & & \\
\hline 1. (Output) & 21.3 & 36 & 36 \\
\hline 2. (Value-added) & 14.0 & 31 & 30 \\
\hline Total & 100 & 100 & 100 \\
\hline
\end{tabular}

${ }^{7}$ Estimates based on Cobb-Douglas Production Function.

${ }^{8}$ Estimates based on Translog function. 


\section{Technical Change and Its Bias}

A more revealing approach to the analysis of the effect of technical change is to examine its respective effects on both labour demand and capital demand simultaneously. We have also measured the technical change effect on input demand by using Hicks technique given in Equation (14), in the manufacturing sector of the economy. ${ }^{9}$

$$
\begin{aligned}
d \ln S= & \left(d \ln W_{L} / d \ln T\right) d \ln T-(d \ln W k / d \ln T) \\
& d \ln T=0.31-0.39=-0.08
\end{aligned}
$$

This result implies that technological change was capital-using and labour-saving. So technical change is labour-saving in the manufacturing sector. That is why the manufacturing sector has failed to generate sufficient employment opportunities in spite of a high rate of growth of manufacturing output during the last two decades. ${ }^{10}$

\section{CONCLUSION AND POLICY IMPLICATIONS}

We have measured technical change, technical efficiency, and their contribution towards growth and their impact on input demand in the manufacturing and agricultural sectors of the economy. We have found that technical change was taking place at a continuous and variable rate. The major contributor to growth of output and value-added in both the sectors was capital, which was contributing over fifty percent. Labour share was about 20 percent in the agricultural sector and about 10 percent in the manufacturing sector. Technical change share was very significant in manufacturing as compared with agriculture. Technical change and its bias were also measured, and it was found that technical change was labour-saving and capitalusing in the manufacturing sector of the economy. This is the very reason behind the fact that although the manufacturing sector of Pakistan has grown at an annual rate of about 6.0 percent during 1970s and at 8.7 percent during 1980s, and its share in GDP has increased from 16.5 percent to about 19 percent, it has failed to generate new opportunities for the labour force, so that the employment growth rate is only about 2 percent. The policy implications suggested here are that as technical change and technical efficiency are the factors crucial to growth (as the experience of developed countries has shown), due attention should be given to technology and to training and proper education of human resources. Technology should be developed according to the needs of the economy, and since it saves labour, alternative steps should be taken to generate new opportunities for employment so that waste (in the form of unemployment) of precious human capital is averted.

${ }^{9}$ Technical change and its biases are measured only for the manufacturing sector as the data on wages in the agricultural sector are not available [see Yanrui (1995)].

${ }^{10}$ Ali (1978) and Sheikh and Iqbal (1992) also found an inverse relationship between technological growth and employment demand in the manufacturing sector of Pakistan. 


\section{REFERENCES}

Abramovitz, Modrd (1956) Resource and Output Trends in the United States Since 1870. American Economic Review 46:2 5-23.

Ahmed, M. A. (1980) Factors which Hinder or Help Productivity Improvement in Asian Region. Country Paper for Pakistan. Tokyo: Asian Productivity Organisation.

Ali, Karamat (1978) Short-term Employment Functions in Manufacturing Industries of Pakistan. The Pakistan Development Review 17:3 333-344.

Berndt, E. R., and L. R. Christensen (1973) The Translog Function and the Substitution of Equipment, Structures, and Labour in US. Manufacturing 192968. Journal of Econometrics 1: 81-114.

Bhavani, T. A. (1991) Technical Efficiency in Indian Modern Small Scale Sector: An Application of Frontier Production Function. Indian Economic Review 26:2 149-166.

Burney, N. A. (1986) Sources of Pakistan's Economic Growth. The Pakistan Development Review 25:4 573-589.

Cheema, Aftab Ahmad (1978) Productivity Trends in the Manufacturing Industries. The Pakistan Development Review 17:1 55-65.

Christensen, L. R., D. W. Jorgenson and L. J. Lau (1973) Transcendental Logarithmic Production Frontiers. Review of Economics and Statistics 55:1 2845.

Corea, H. (1976) Sources of Economic Growth in Latin America. Southern Economic Journal 37:1 17-31.

Cornwell, C., P. Schmidt, and R. C. Sickles (1990) Production Frontiers with Crosssectional and Time Series Variations in Efficiency Levels. Journal of Econometrics 46: 185-200.

Denison, Edward F. (1967) Sources of Postwar Growth in Nine Western Countries. American Economic Review 57:2 325-336.

Fare, R., Shawna Grosskopf, Mary Norris, and Z. Zhang (1994) Productivity Growth, Technical Progress and Efficiency in Industrialised Countries. American Economic Review 84:1 66-83.

Fecher, F., and P. Pestieau (1993) Efficiency and Competition in OECD Financial Services. In O. Harold, C. A. Fried, Knox Lovell and S. Shelton (eds) The Measurement of Productivity Efficiency: Techniques and Applications. New York: Oxford University Press.

Ferguson, C. (1965) Time Series Production Functions and Technological Progress in American Manufacturing Industry. Journal of Political Economy 73:2 135147. 
Griliches, Zvi (1963) The Sources of Measured Productivity Growth: United States Agriculture, 1940-1960. Journal of Political Economy 71:4 331-346.

Hassan, Y. Aly, and Richard Grabawski (1988) Technical Change, Technical Efficiency, and Input Usage in Taiwanese Agricultural Growth. Applied Economics 20.

Hulten, C. R. (1973) The Measurement of Total Factor Productivity in United States Manufacturing: 1948-66. Ph. D. Dissertation. Berkeley: University of California.

Khan, C., W. Hongchang, Z. Yuxin, G. H. Jefferson, and T. G. Rawski (1988) Productivity Change in Chinese Industry: 1953-1985. Journal of Comparative Economics 12:4 570-591.

Kang, Jung M., and Jene K. Kwon (1988) An Estimation of Import Demand, Export Supply and Technical Change for Korea. Applied Economics 20: 1661-1674.

Kemal, A. R. (1981) Substitution Elasticities in the Large Scale Manufacturing Industries of Pakistan. The Pakistan Development Review 20:1 1-36.

Kemal, A. R., and Islam Ahmed (1992) Report of the Sub-committee on Sources of Growth in Pakistan. Islamabad: Pakistan Institute of Development Economics.

Kendrick, John W. (1956) Productivity Trends: Capital and Labour. Review of Economics and Statistics, August.

Kendrick, John W. (1973) Postwar Productivity Trends in United States: 1948-66. New York: National Bureau of Economic Research.

Kennedy, C., and A. P. Thrilwall (1972) Surveys in Applied Economics: Technical Change. Economic Journal 82:325 12-72.

Nadiri, M. Ishaq (1970) Some Approaches to the Theory and Measurement of Total Factor Productivity: A Survey. Journal of Economic Literature 85:4 1137-1177.

Nelson, R. (1981) Research on Productivity Growth and Productivity Differences: Dead Ends and New Departures. Journal of Economic Literature 19:3 10291064.

Pakistan, Government of (Various Issues) Census of Manufacturing Industries. Islamabad: Pakistan Statistics Division.

Pakistan, Government of (Various Issues) Economic Surveys. Islamabad: Economic Adviser's Wing, Finance Division.

Pakistan, Government of (Various Issues) Labour Force Surveys. Islamabad: Federal Bureau of Statistics, Economic Affairs and Statistics Division.

Robinson, Sherman (1971) Sources of Growth in Less Developed Countries: A Cross-section Study. Quarterly Journal of Economics 85:3 391-408.

Salter, W. (1966) Productivity and Technical Change. (2nd edition.) London: Cambridge University Press,

Schultz, T. W. (1964) Transforming Traditional Agriculture. New Haven: Yale University Press. 
Sheikh, K. H., and Z. Iqbal (1992) Short-term Employment Functions in Manufacturing Industries: An Empirical Analysis for Pakistan. The Pakistan Development Review 31:4 1267-1277.

Solow, R. M. (1957) Technical Change and Aggregate Production Function. Review of Economics and Statistics 39:3 312-320.

Solow, R. M. (1960) Investment and Technical Progress in Mathematical Methods in the Social Sciences. New York: Stanford University Press. 89-104.

Wizarat, Shahida (1981) Technological Change in Pakistan's Agriculture: 1953-54 to 1978-79. The Pakistan Development Review 20:1 427-445.

Wizarat, Shahida (1989) Sources of Growth in Pakistan's Large-scale Manufacturing Sector: 1955-56 to 1980-81. Pakistan Economic and Social Review 27:2 139159.

Yanrui, Wu (1995) Productivity Growth, Technological Progress, and Technical Efficiency Change in China: A Three Sector Analysis. Journal of Comparative Economics 21:2 207-229.

Zellner, A. (1962) An Efficient Method of Estimating Seemingly Unrelated Regressions and Tests for Aggregation Bias. Journal of American Statistical Association, June.

Zellner, A. (1963) Estimators for Seemingly Unrelated Regression Equation: Some Exact Finite Sample Results. Journal of American Statistical Association, December. 